\title{
HIDUP DALAM KERAGAMAN: MASALAH DAN WAWASAN KERAGAMAN
}

\author{
Barnabas Ludji \\ STT Cipanas
}

barnabasludji28854@gmail.com

\begin{abstract}
As God's people, the church needs to realize that diversity is an essential nature of the Unitary State of the Republic of Indonesia. Efforts to homogenize nations that are diverse in race, ethnicity, culture and religion must be seen as efforts to divide the nation. Therefore religions in Indonesia, especially the Church of God must really be a motivator and encourage their citizens to be truly aware of the diversity of the nation and take part in fostering a life of life that respects diversity and tolerates life with fellow human beings with everything attached to himself, including his religion and culture.

In connection with the above, the church leaders and theologians must really try to find an understanding of faith that encourages people to accept differences and be able to build a tolerant life together. Efforts in that direction can be built through the perspectives of all fields of theological studies. This paper contains efforts to build a tolerant shared life from a systematic perspective. Theology of Religions and the Biblical (Old Testament). The dogmatic perspective sees two basic needs, namely to nurture and increasingly take root in the faith of church members, and the need to determine attitudes towards the presence of other religious life together. Without forgetting the universal nature of religion as an expression of religious awareness. From an ethical perspective feel the need to develop global ethics that are universal. From the perspective of the science of religions it is necessary to highlight the verses of the Scriptures possessed by each religion that are universal. While the Biblical perspective sees the importance of Christians understanding their holy books diachronically and holistically. Because improper ways of understanding the Bible make possible the birth of exclusive fundamentalists. Central themes, such as love, justice, truth, peace, redemption, goodness, and life are believed to be from God, all of which are universal. All biblical texts, if understood, diachronically, then the text messages are the central themes already mentioned.
\end{abstract}

Key Words: love (life); truth / justice of God; diversity; tolerance;

\section{ABSTRAK}

Sebagai umat Allah, gereja perlu menyadari bahwa keanekaragaman merupakan sifat hakiki dari Negara Kesatuan Republik Indonesia. Usaha untuk menyeragamkan bangsa yang beranekaragam ras, suku, kebudayaan dan agama harus dilihat sebagai upaya yang bisa memecah belah bangsa. Karena itu, agama-agama di Indonesia, khususnya Gereja Tuhan harus sungguh menjadi pemberi motivasi dan mendorong warganya untuk sungguh-sungguh menyadari akan keanekaragaman bangsa dan ikut mengambil bagian dalam menumbuhkembangkan peri kehidupan yang menghargai keanekaragaman dan hidup bertoleransi dengan sesama manusia dengan segala sesuatu yang melekat pada dirinya, termasuk agama dan kebudayaanya.

Berhubungan dengan hal di atas, maka para pemimpin gereja dan para teolog harus sungguh-sungguh berusaha menemukan pemahaman iman yang mendorong umat bisa menerima adanya perbedaan-perbedaan dan mampu membangun kehidupan bersama yang bertoleransi. Upaya-upaya ke arah itu bisa dibangun melalui perspektif semua bidang studi teologi. Tulisan ini memuat upaya membagun kehidupan bersama yang bertoleransi dari perspektif sistimatika. Ilmu agama-agama dan Biblika (Perjanjian Lama). Perspektif dogmatis melihat adanya dua kebutuhan dasar, yaitu untuk memelihara dan semakin mengakarkan iman para warga gereja, dan kebutuhan untuk menentukan sikap terhadap hadirnya kehidupan bersama religious lainnya. Tanpa melupakan hakikat universal agama sebagai suatu ungkapan kesadaran religious. Dari perspektif etika merasa perlu mengembangkan etika global 
yang bersifat universal. Dari perspektif ilmu agama-agama perlu menonjolkan ayat-ayat Kitab Suci yang dimiliki masing-masing agama yang bersifat universal. Sedangkan perpspektif Biblika melihat pentingnya orang kristen memahami Kitab sucinya secara diakronis dan secara holistik. Sebab cara memehami Alkitab yang tidak pas memungkinkan lahirnya kaum fundamentalisme yang eksklusif. Tema-tema sentral, seperti kasih, keadilan, kebenaran, perdamaian, penebusan, kebaikan, dan kehidupan diyakini sebagai yang berasal dari Allah, semuanya bersifat universal. Semua teks Alkitab jika dipahami secara dakronis, maka pesan-pesan teks itu adalah tema-tema sentral yang sudah disebutkan.

kata Kunci: kasih (kehidupan); kebenaran/keadilan Allah; keanekaragaman; toleransi;

\section{HIDUP DALAM KERAGAMAN: MASALAH DAN WAWASAN KERAGAMAN}

(Suatu kajian teologis dari sudut pandang dogmatika, Etika, Teologi Agama-Agama dan Perjanjian Lama)

\section{Keragaman Adalah Sifat atau Hakikat Bangsa}

Keragaman bangsa Indonesia mustinya tidak perlu dipersoalkan lagi. Karena keragaman adalah salah satu ciri atau sifat hakiki bangsa Indonesia. Mengapa? Karena sebelum merdeka, seluruh wilayah negeri ini dihuni oleh berbagai suku, ras yang memiliki agama dan kebudayaan yang berbeda-beda. Sebelum merdeka, mereka sudah beragam. Lebih jauh dari hanya perbedaan/keragaman suku, ras, agama dan budaya, ialah, bahwa setiap orang dari suatu suku, ras, agama atau golongan saja sudah berbeda-beda satu sama lainnnya. Misalnya, orang yang beragama Kristen sudah jelas beragam suku, ras dan budaya. Demikian juga yang beragama Islam, pasti beraneka ras, dan budaya. Suku Batak, ada Batak Toba dan ada Batak Karo. Wajah dari setiap orang Batak Toba ataupun Batak Karo saja sudah berbeda-beda. Ada yang rambutnya keriting dan ada yang rambutnya lurus. Wajah anak-anak dari satu ayah, satu ibu saja sudah berbeda-beda. Kalau memang tujuan Tuhan menciptakan mansia yang berbeda-beda dan beranekaragam itu adalah uniform, mengapa Tuhan menciptakan manusia itu berbeda-beda? Adam diciptakan dan Hawa pun diciptakan bukan untuk terpisah-pisah, melainkan untuk saling bahu-membahu, agar saling menguatkan dalam kehidupan di bumi. Begitu juga dengan berbagai suku, ras, dan agama yang ada di negeri ini.

Itulah sebabnya ketika bangsa ini berjuang untuk bisa lahir, mereka sama-sama bahu membahu. Pejuang-pejuang bangsa yang beragam itu bersatu padu tanpa melihat dari suku atau agama mana. Semua lebur menjadi satu. Bersatu padunya seluruh suku bangsa dan ras yang menganut agama yang berbeda satu sama lainnya untuk meraih cita-cita bersama, itulah kekuatan dari suku-suku, ras-ras yang berbedabeda agama itu. Hal ini sudah terbukti dalam sejarah. Pancasila lahir dari keanekaragaman suku, ras dan kebudayaan, sehingga mustinya Pancasila juga bisa dilihat sebagai yang melegalkan keragaman bangsa ini, tetapi juga sekaligus melegalkan kesatuan bangsa. Karena itu, siapapun yang menolak Pancasila, dia adalah pelanggar dan penyangkalan terhadap kodrat atau eksistensi bangsa yang beragam ini. Suatu penyangkalan yang tidak mungkin meniadakan keragaman. Sebab keragaman adalah eksistensi setiap anak bangsa. Mengakui, menghargai dan memelihara keragaman adalah kehidupan bagi setiap anak bangsa. 
Setelah meraih kemerdekaan muncul perjuangan-perjuangan yang ingin menjadi kelompok yang diutamakan, bahkan munculah usaha-usaha menggantikan keragaman dengan keseragaman (uniform). Munculnya berbagai pemberontakan dari kelompok yang mengatasnamakan agama tertentu; kelompok politik tertentu atau pun kelompok idiologi tertentu. Benih-benih perjuangan serupa masih terasa sampai sekarang. Misalnya, kelompok radikalisme yang saling bahu membahu dengan perjuangan kelompok sosial politik. Perjuangan-perjuangan seperti di atas, masing-masing kelompok memiliki motivasi dan tujuan. Ada yang tujuan kekuasaan sekaligus mengumpulkan harta. Ada yang tujuan agama.

Para pejuang bangsa seperti Bung Karno memang sejak awal sudah menyadari tentang akan adanya gejolak-gejolak penyeragaman terhadap keanekaragaman bangsa Indonesia. Hebatnya Bung Karno adalah, karena ia menggali nilai-nilai universal yang ada pada ras,suku, agama dan kebudayaan yang beranekaragam dinegeri ini. Nilai-nilai yang ia temukan itu dirumuskan secara tepat, benar dan baik dalam butir-butir Pancasila. Itulah sebabnya Bung Karno pernah mengucapkan kata-kata ini, "Saudara-saudara, Pancasila adalah jiwa kita, bukan hanya jiwaku." Agaknya dengan ucapan ini Bung Karno mau menegaskan, bahwa Pacasila itu adalah eksistensi atau keberadaan dan milik seluruh anak bangsa. Jangan diganggu gugat, sebab jika ada orang yang mengganggu keragaman, berarti ia mengganggu dirinya sendiri, yang juga menyebabkan orang lain terganggu.

Butir-butir Pancasila tidak diindoktrinasi, tetapi ditawarkan dan dibahas bersama oleh pendahulu kita. Walau pun melalui percakapan yang memakan waktu panjang, akhirnya para faunding fathers and mothers sepakat menjadikan Pancasila sebagai dasar kehidupan berbangsa dan bernegara. Pancasila adalah fondasi Negara. Jika fondasi dihancurkan, bangunannya juga akan roboh. Kalau saja para presiden yang pernah berkuasa di negeri ini secara konsisten menjalankan pemerintahannya dengan tetap terus menumbuh kembangkan nilai-nilai luhur Pancasila, mungkin bangsa ini sudah bisa mengakhiri atau paling tidak meminimalisasi suara-suara dan perjuangan-perjuangan yang masih mempertanyakan identitas bangsa. Sebenarnya ketika bangsa ini masih diganggu oleh keinginan-keinginan menggantikan dasar Negara Pancasila dengan dasar yang lain, bangsa ini seolah-olah belum merdeka. Itulah sebabnya bangsa ini masih berjalan di tempat. Bangsa yang maju di dunia ini, adalah bangsa yang tidak lagi mempersoalkan identitasnya. Mereka sudah sampai kepada pengakuan dunia atas kebesaran dan kehebatan bangsa di seluruh bidang kehidupan.Bangsa lain sudah sampai ke planit Mars kita masih berkutak-kutik dengan persoalan Indonesia milik siapa atau siapa itu Indonesia? Kalimantan milik siapa, Papua milik siapa; wilayah A milik siapa dan wilayah B milik siapa. Pada hal kurang lebih sejak 74 tahun yang lalu seluruh wilayah Nusantara sudah sah menjadi milik bersama seluruh bangsa Indonesia. Bangsa lain sudah membangun kapal induk raksasa guna mempertahan wilayah kedaulatan bangsa mereka. Mereka memiliki berlusin-lusin kapal selam untuk mempertahankan kedaulan wilayah mereka. Kita baru saja ingin menambah armada kapal selam dari satu buah menjadi tiga dan seterusnya kita sudah terjebak dengan masalah internal, seperti rongrongan terhadap pemerintahan yang yang sah. Demo anargis belum juga berhenti. Bagaimana mungkin pemerintah bisa dengan tenang membangun bangsa untuk lebih maju. Dahulu kita dijajah oleh bangsa lain selama ratusan tahun, karena penjajah menjalankan politik memecahbelah. Kemudian bangsa kita bersatu padu mengusir penjajah dan berhasil memproklamasikan kemerdekaan. Setelah merdeka politik pecah belah itu dilakukan lagi kelompok-kelompok bangsa kita sendiri, entah itu kelompok politik maupun kelompok agama.

\footnotetext{
${ }^{1}$ Disunting dari The Syaiful Cahyadi oleh Alfi Arifian, SEMUA TENTANG SUKARNO. Jika Sukarno tidak ada, mungkin Indonesia tidak ada, Yogyakarta, Rumah Sukarno, 2018, hl. XV.
} 
Kita harus menyadari bahwa jika relasi religious dibangun atas doktrin-doktrin tertentu yang dianut setiap agama, maka relasi yang harmonis dan toleran antarumat beragama diragukan akan bisa terbangun. Yang terjadi selama ini masing-masing agama mempersoalkan doktrin agama mana yang paling benar. Jika benturan dokrin yang dikembangkan sampai dunia kiamat juga intoleransi tidak pernah selesai. Namun yang pasti pada semua agama ada yang disebut dengan nilai-nilai kemanusiaan yang universal. Nilai-nilai inilah yang bisa mengubah sikap intoleran menjadi sikap yang toleran dari umat beragama. Sepanjang sejarah, bangsa Indonesia diganggu oleh gerakan radikalisme agama yang menginginkan dasar Negara yang lain. Sampai saat ini pun banyak orang yang baik secara terang-terangan mau pun secara tertutup (gerakan di bawah tanah) yang ingin menggantikan dasar Pancasila dengan dasar yang lain, yang ingin menghapus kenyataan keberagaman bangsa ini. Yang beragam dibenturkan satu sama lain.

Karena itu, seluruh komponen bangsa perlu bekerja keras untuk memerangi roh radikalisme yang ada pada banyak agama di negeri ini. Seluruh bangsa (whole people) perlu menyadari situasi bangsa yang demikian dan berpartisipasi secara aktif dan penuh memerangi roh radikalisme yang ada pada agamaagama yang hidup di negeri ini.

Agama memiliki potensi melahirkan radikalisme. Sekaligus menyebabkan Negara porak poranda akibat radikalisme. Kita bisa menyaksikan bagaimana kekacauan di Timur Tengah sekarang. Afganistan juga merupakan salah satu Negara yang kacau balau akibat radikalisme atau pun fundamentalisme agama. Yusuf Kalla mengatakan, "Konflik di sejumlah Negara Islam semestinya menjadi pelajaran bagi seluruh masyarakat, khususnya umat Islam di Indonesia." ${ }^{2}$ Beliau memberikan contoh situasi terkini di Timur Tengah, Arab Saudi yang mengebom Yaman; Irak diblokade; Libya sudah habis-habisan; Afganistan hancur-hancuran. Itulah dunia Islam sekarang, Tutur Yusuf Kalla. Itulah sebabnya Yusuf Kalla menghimbau agar para pemuka agama selalu mengedepankan perdamaian dan harapan saat berdakwah. ${ }^{3}$ Himbauan Yusuf Kalla ini tentu saja ditujukan kepada tokoh-tokoh semua agama di Indonesia, sebab agama-agama berada dan selalu berinteraksi serta bersinggungan satu sama lain di negeri ini.

\section{Konflik-Konflik Agama}

K.H. Hasyim Muzadi mengatakan konflik antarumat beragama tidak hanya disebabkan oleh masalah agama itu sendiri. Tetapi juga ditentukan oleh factor geopolitik, idiologi, sosial dan ekonomi. Untuk memperkuat pernyataannya, Muzadi mencontohkan, orang sangat sulit mendirikan Gereja di Bandung atau Bogor, Jawa Barat. Hal ini tentu saja berbeda ketika orang begitu mudah mendirikan gedung gereja di Magelang atau Tumanggung, Jawa Tengah. Menurut Muzadi, hal itu terjadi karena faktor geopolitik dalam tingkat local. Pendukung mana yang memungkinkan seseorang menjadi kepala daerah dan konsesi apa saat ia menjadi kepala daerah akan menentukan kebijakan kepala daerah. Agaknya Muzadi mengutip pendapat ini dari Kompas, Rabu 16 Februari, 2011, hl. 1. ${ }^{4}$ Dalam hal ini saya juga mengutip apa yang dikatakan Hasrullah dalam bukunya yang berjudul, Dendam Konflik Poso. Ia mengatakan bahwa konflik di Poso bukanlah konflik masyarakat biasa. Pemicu utamanya adalah skenario

\footnotetext{
${ }^{2}$ Kompas, Sabtu, 12 Oktober, 2019, hl. 3.

${ }^{3}$ Ibid.

${ }^{4}$ Leonardus Samosir dalam Eddy Kristiyanto. William Chang (editor), Mozaik yang “harus” Serasi: Konflik Agama dalam Multi Kulturalisme,Jakarta, Obor, hl. 80.
} 
elit politik yang berebut kekausaan di sana. Hal itu berkaitan dengan power sharing yang tidak adil bagi kelompok agama tertentu. ${ }^{5}$

Di sekitar rumah saya ada sebuah masjid yang dibangun belasan tahun yang lalu. Sejak awal rumah ibadah dimaksud diprotes oleh warga setempat yang satu agama dengan pendiri rumah ibadah tersebut. Sampai saat ini rumah ibadah itu tidak digunakan untuk ibadah umat. Warga setempat memprotesnya mungkin, karena sebelumnya sudah ada dua rumah ibadah di wilayah itu. Intoleransi antara umat yang satu agamapun sudah sering terjadi, mungkin karena perbedaan doktrin

Peristiwa lain yang disebutkan adalah konflik agama yang disebabkan oleh konflik yang bersifat pribadi. Misalnya peristiwa pembakaran pesantren Syiah di Sampang Madura pada penghujung tahun 2011 dianggap tidak murni konflik aliran. Peristiwa melibatkan konflik pribadi dari kakak beradik, karena persoalan yang bersifat pribadi. Penjelasan selanjutnya bisa dibaca dalam buku, Multikulturalisme, Kekayaan dan Tantangannya di Indonesia. ${ }^{6}$

Gereja-gereja di Indonesia yang makin bertambah banyak denominasinya, juga bisa menunjukkan tentang adanya perbedaan-perbedaan doktrin yang mungkin saja melahirkan ketegangan-ketegangan baik secara terbuka atau pun secara diam-diam. Karena itu, perpecahan gereja bisa terjadi di mana-mana. Setiap gereja mungkin saja melakukan klaim-klaim kebenaran yang bisa menimbulkan sikap saling menghakimi satu sama lain. Pada waktunya gereja-gereja bisa juga menjadi penebar roh perpecahan di negeri ini. Fundamentalisme agama memang sedang menebar benih perpecahan di negeri ini. Baik yang dilakukan demi kepentingan agama itu sendiri atau pun demi kelompok agama dan kelompok politik yang haus kekuasaan yang saling memanfaatkan. Siapakah yang menyebabkan semua ini? Apakah skenario dari luar yang memanfaatkan potensi-potensi perpecahan yang ada di bangsa ini? Saya tidak bisa memastikan ini. Mudah-mudahan sudah ada penelitian terhadap hal-hal ini.

Seharusnya agama-agama menjadi perekat bangsa yang dapat dikembangkan baik melalui konsep-konsep teologi yang dinamis dan menghidupkan, maupun melalui tindakan dan relasi sosialekonomi yang menyentuh nilai-nilai kemanusiaan yang universal. Tokoh-tokoh kristen sebenarnya sudah banyak yang memberikan pemikiran-pemikiran yang membangun kebersamaan dan menghindari sikapsikap intoleransi dan karakter radikalisme.

\section{Beberapa Sumbangan Pemikiran Para Teolog}

Sebatas yang saya baca, saya bisa menyebutkan beberapa tokoh dengan buah pikiran mereka secara singkat. Pertama, Broto S. Wiryotinoyo, Yusak Tridarmanto dan Bambang Suteng Sulasmono dengan judul artikel, "Kepedulian Kristen terhadap kehidupan bersama Negrawi." Pada akhir tulisan mereka yang cukup panjang itu (hl 49-107), mereka menyimpulkan tiga hal. Pertama, berhubung degan tantangan masa depan yang semakin kompleks, maka persatuan dan kesatuan bangsa harus semakin dimantapkan dan bukan sebaliknya dirapuhkan. Untuk itu, perlu terpeliharanya perhubungan antar Negara dan Agama, dan kehidupan keagamaan, perhubungan antarumat beragama yang sejalan dengan prinsipprinsip dasar dari dasar Negara Pancasila. Hal ini sangat dibutuhkan untuk menyongsong masa depan cita-

\footnotetext{
${ }^{5}$ Harullah, Dendam Konflik Poso (Periode 1998-2001), Konflik Poso dari Perspektif Komunikasi Politik, Jakarta, Penerbit Gramedia, 2014, hl. 80-81.

${ }^{6}$ Ibid.
} 
cita bangsa yang diharapkan oleh seluruh bangsa kita. Kedua, tampak ada dua kebutuhan dasar, yaitu untuk memelihara dan semakin mengakarkan iman para warga gereja, dan kebutuhan untuk menentukan sikap terhadap hadirnya kehidupan bersama religious lainnya. Tanpa melupakan hakikat universal agama sebagai suatu ungkapan kesadaran religious. Kebutuhan yang pertama dapat lebih terpenuhi melalui pemahaman yang terus menerus terhadap isi pokok iman, yang berpusat pada praduga agama. Dalam hubungan dengan ini, pemahaman tentang hakikat universal agama sebagai ungkapan konkrit kesadaran religious akan sangat berguna untuk membentengi Gereja dari ancaman munculnya sikap fanatik dan sentimen terhadap agama lain. Walaupun betul bahwa Gereja tidak mungkin mengingkari pengakuan imannya sebagai praduga agama. Dengan cara ini gereja dapat menjauhkan diri dari upaya menggunakan praduga agamanya sebagai satu-satunya ukuran untuk menentukan sikapnya terhadap agama-agaama lain. Selanjutnya dikatakan dengan memberlakukan etika perdamaian yang dimilikinya, maka Gereja akan mampu menempatkan agama-agama lain sebagai patner aktualisasi diri di tengah-tengah masyarakat bangsa dan Negara, yaitu Negara Republik Indonesia. Ketiga, dalam mengusahakan pemikiran yang lengkap tentang HAM perlu penyebaran lebih lanjut hak-hak asasi inti manusia. ${ }^{7}$ Memang apa yang dikatakan penulis-penulis di atas merupakan salah satu usaha untuk kebersamaan. Namun jalan keluar yang dikemukakan adalah terus menerus mempelajari pokok-pokok pengakuan iman yang merupakan praduga bagi orang beriman. Jika cara mempelajarinya tidak berubah, maka tidak akan terjadi perubahan berarti dalam umat bersikap terhadap mereka yang berbeda darinya. Jadi menurut saya perlu ada perubahan metode dalam cara mempelajarinya.

Tulisan berikut yang ingin saya sampaikan adalah Tulisan Dr. Djaka Soetapa, yang berjudul, Dasar Hidup Bersama Dalam kemajemukan Agama. Artikel ini ditulis dalam buku yang sudah disebutkan di atas (Keadilan Dalam Kemajemukan). Soetapa mengatakan bahwa kerukunan dan keselarasan hubungan antarumat beragama menjadi pilar yang menentukan dalam kesatuan dan persatuan bangsa, sebab pengalaman kehidupan keagamaan yang cenderung memiliki watak yang eksklusif dapat menjadi kendala dan penghambat bagi upaya kerukunan dan keselarasan dimaksud. ${ }^{8}$ Karena itu, menurut Soetapa, kajian terhadap bagian-bagian Kitab-kitab Suci umat beragama yang berbicara tentang hal-hal yang memungkinkan bertumnbuhnya sikap hidup yang toleransi dan selaras di antara sesama umat beragama sangat diperlukan. Tentu usaha ini harus dilihat sebagai salah satu upaya dan bukan satu-satunya upaya. Apa yang dikatakan dan yang diupayakan oleh Soetapa memiliki alasan yang kuat, karena peranan agama cukup terasa sebagai penyebab minculnya konflik antar umat beragama atau antarkelompok dalam masyarakat bangsa Indonesia. Menurut penelitian Leonardus Samosir yang ditulisnya dalam artikel yang berjudul Mozaik yang "harus' Serasi: Konflik Agama, mengatakan, 'konflik antarkelompok agama atau konflik agama yang marak dalam decade ini memberikan warning kepada Negara Indonesia yang hendak mendukung keragaman dalam kesatuan. ${ }^{9}$

Soetapa adalah seorang ahli Ilmu Agama-agama. Dalam tulisannya, Soetapa menjelaskan beberapa ayat Al-Qur'an dan Al-Kitab yang berbicara hal-hal yang memperlihatkan adanya keanekaragaman pada agama-agama awal, baik yang dihadapi umat Allah zaman Perjanjan Lama, mau pun umat zaman Perjanjian Baru dan juga agama Islam. Tentu saja apa yang dikerjakan Sortapa

\footnotetext{
${ }^{7}$ Sularso Sopater cs, (penyunting), Keadilan dalam Kemajemukan, Jakarta, Pustaka Sinar Harapan, hl. 106-107.

${ }^{8}$ Ibid. 109

${ }^{9}$ A.Eddy Kristiyanto dan William Chang (editor), Multi Kulturalisme, Mozaik yang "harus" Serasi: Konflik Agama, Jakarta, Obor, 2014, hl. 79.
} 
merupakan upaya membuka wawasan umat beragama untuk menjadi manusia Indonesia yang saling menghormati dan saling menghargai dalam keberagaman dan mengokohkan persatuan dan kesatuan bangsa. Apa yang dikerjakan Soetapa dapat dibaca daalam buku yang sudah disebutkan (Keadilan dalam Kemajemukan). ${ }^{10}$ Ayat-ayat Alkitab yang dikemukakan oleh Soetapa, memang sesuai yang diharapkan, namun masih sangat terbatas, karena Soetapa masih terbatas pada teks-teks tertentu dan belum melihat isu-isu atau tema-tema sentral Alkitab yang seharusnya sangat bersifat universal yang menembus batasbatas kesukuan, ras, dan keagamaan, karena menyentuh nilai-nilai kemanusiaan dan kebutuhan manusia yang hakiki. Misalnya, kehidupan, kasih, kebenaran, keadilan, pembebasan (kemerdekaan), pengampunan dan penebusan yang meliputi seluruh dimensi kehidupan semua makluk.

Ahli lain yang sudah menyumbangkan pemikiran teologinya bagi kehidupan bersama yang saling menghargai dan menghormati adalah Th. Sumartana. Sumartana menulis artikel yang yang berjudul, "Globalisasi, Pluralisme dan Dialog Antar Agama," "11 Sumartana mengatakan bahwa agama-agama tidak siap menghadapi kenyataan kenyataan kemajemukan agama. Oleh karena itu, kita belum memikirkan secara sungguh-sungguh konsekwensi kemajemukan di masyarakat itu bagi kehidupan batin, kehidupan mental, intelektual dan kehidupan spiritual kita. Apalagi menyangkut soal pluralisme agama, masalah yang dihadapi memang lebih sulit, sebab agama-agama mempunyai ciri khusus, dan sulit untuk tidak menyinggung soal kebenaran yang dianggap absolut dan sifatnya non-negotiable. ${ }^{12}$ Walaupun yang dianggap kebenaran absolut oleh masyarakat agama itu adalah pemikiran-pemikiran yang dirumuskan oleh para pemimpin agama sejak ratusan atau pun ribuan tahun yang lalu untuk menjawab persoalan agama atau manusia pada zamannya, tetapi belum tentu relevan dengan pergumulan agama masa kini.

Hal lain yang dilihat Sumartana ialah, adanya perkembangan pemikiran teologi yang belum merata, sehingga sering muncul kesenjangan antara pemikir-pemikir pada tingkat elit dengan kehidupan umat yang nyata. Di satu pihak agama-agama tidak bisa menghindar untuk bertemu satu dengan yang lain. Di pihak lain malahan mereka harus bekerja sama dan menganggap kerja sama selaku keharusan bagi kesejahteraan bersama masyarakat. Namun kerja sama dan pergaulan sering tidak memperoleh dukungan refleksi teologis yang diperlukan. Sehingga tidak serentak, dan sering memperoleh hambatan dari pemimpin elit keagamaan tertentu yang belum mampu memberikan basis yang lebih terbuka dan mampu meletakkan persoalan pluralisme agama secara proporsional. ${ }^{13}$ Menurut saya, ucapan Sumartana mendorong pemimpin agama untuk bekerja keras untuk merefleksikan pesan-pesan teologis yang terdapat pada Kitab Suci masing-masing agama. Kisah-kisah tentang penciptaan dalam Alkitab Kristen, misalnya sudah pasti berbicara tentang Allah yang universal, karena Dialah yang menjadikan langit dan bumi serta segala isinya, termasuk manusia yang menjadi bapa leluhur seluruh umat manusia. Manusia hanya ada satu yang terdiri dari seluruh suku, bangsa dan ras yang menghuni seantero bumi. Hanya kesombonganlah yang telah menhancurkan umat manusia. Ketika manusia ingin menggantikan kedudukan Allah, maka sesamanya telah menjadi mangsa dan kesombongan itulah yang telah menjadikan manusia predator bagi sasama makluknya. Karena itu, yang seharusnya diperjuangkan dan direfleksikan dalam perjalanan agama-agama di bumi kecil yang satu ini, bukanlah spiritualitas yang memecah belah, melainkan spiritualitas kebersamaan. Saya percaya bahwa pada Kitab Suci setiap agama, spiritulitas kebersamaan itu

\footnotetext{
${ }^{10}$ Djaka Soetapa, Sularso Sopater cs (penyunting), Dasar Hidup Bersama dalam Kemajemukan Agama, hl. 108-123.

${ }^{11}$ Th. Sumartana, dalam buku, Keadilan dan Kemajemukan, Globalisasi, Pluralisme dan Dialog Antar Agama, ibid. hl.124-137.

${ }^{12}$ Ibid. hl. 125

${ }^{13}$ Ibid. 125.
} 
pasti jauh lebih kuat daripada spiritulitas pemecah belah, bahkan patut diduga, roh pemecah tidak menjadi misi dari Kitab Sici setiap agama. Kitab Suci pasti lebih banyak berbicara tentang masalah-masalah kemanusiaan yang bersifat universal. Kitab Suci berbicara tentang kasih, keadilan dan kebenaran Allah yang menjadi landasan fundamental bagi relasi kemanusiaan antar umat manusia dalam berbagai dimensi kehidupan.

Akibat globalisasi dan perkembangan teknologi telah membuat bumi menjadi satu. Setiap kelompok kecil telah terangkum dalam bumi yang semakin kecil. Persoalannya apakah manusia benarbenar sudah bersatu secara spiritual? Kenyataannya sejarah telah berjalan sangat cepat dan sebagian besar umat manusia tertinggal di belakang. Sebagian warga masyarakat tidak siap dan gagal menanggapi kenyataan dunia yang telah menjadi satu. Sumartana mengatakan kita memerlukan sebuah spiritualtas global, bahkan sebuah etika global untuk bisa hidup bersama secara tepat di masa depan. ${ }^{14}$

Beliau juga melihat persoalan lain, yaitu di pihak lain globalisasi telah membuat dunia menjadi kecil dan menjadi satu. Namun dilain pihak sifat frakmentasi local juga semakin kuat. Eksklusif suku juga menguat. Mereka bersatu untuk kepentingan-kepentingan suku mereka. orang lain yang berada di wilayah suku yang berbeda dianggap sebagai orang lain. Lalu masyarakat terpecah menjadi kelompok "in-group" dan "out-group". Sumartana juga mengatakan bahwa secara gerejawi dan teologis, kita mesih berorientasi pada orientasi suku, sebagai sebentuk pandangan filosofis yang bertentangan dengan gejala globalisasi. Selanjut ia mengatakan, kita membutuhkan bangunan teologis dan bentuk spiritualitas yang mampu merangkum seluruh dunia dan semua manusia dalam sebuah kesatuan yang bisa menerima manusia sebagai sebuah kesatuan makluk. ${ }^{15}$ Sumartana sebagai ahli sistimatika, maka dia berusaha menjelaskan apa yang harus dilakukan gereja dan para teolog untuk membangun relasi kebersamaan dalam zaman globalisasi. Menurut dia, inti dari persoalan etika dalam hubungan antaragama adalah bagaimana kita menghormati sesama manusia dalam totalitasnya yang juga terbentuk oleh iman keagamaannya. Di pihak lain, bagaimana pula menghargai integritas agama orang lain, dengan segala riwayat dan sejarahnya yang unik. Sumartana dalam hal ini sangat menekan sebuah relasi yang yang terbuka, jujur dan tanpa apriori. ${ }^{16}$ Masih banyak teolog yang sudah memberikan sumbangan pemikiran untuk memupuk kehidupan bersama yang toleran dan harmonis.

Dari pemikiran teolog di atas kita dapat melihat adanya sikap-sikap umat beragama yang bersifat eksklusif, primordial dan intoleran yang disebabkan adanya pemahaman iman yang dangkal terhadap pokok pengajaran iman. Hal ini disebabkan oleh sikap tertutup terhadap orang yang beragama lain, karena fanatisme agama yang berlebihan. Juga karena tidak adanya usaha yang serius untuk menemukan kemungkinan-kemungkinan membangun spiritualitas kebersamaan, kedamaian dan toleran.

Para ahli juga melihat adanya paradigma-paradigma yang memungkinkan pembangunan teologi dan spiritualitas kebersamaan dan toleran. Para teolog yang menulis artikel sesuai keahlian mereka, memastikan kepada kita bahwa para teolog kristen bisa menemukan teologi dan spiritualitas kesatuan manusia, bahkan makluk dari berbagai disiplin ilmu teologi.

\footnotetext{
${ }^{14}$ Ibid. 127

${ }^{15}$ Ibid.

${ }^{16}$ Ibid. hl. 129.
} 
Namun saya juga harus mengatakan bahwa persoalan umat beragama di Indonesia tidak sematamata hanya karena agama itu sendiri. walaupun saya juga harus mengatakan bahwa agama-agama juga punya andil bagi lahirnya sikap intoleran, seperti yang disorot di atas. Bentrok antarumat beragama di Indonesia berkaitan juga dengan permainan elit politik yang berebut kekuasaan.

Sebagai yang menekuni biblika, khususnya Perjanjian Lama, saya melihat bahwa Alkitab Perjanjian Lama pada umumnya banyak berbicara tentang masalah-masalah manusia secara universal. Alkitab banyak berbicata tentang keadilan dan kebenaran, banyak berbicara tentang jalan keluar bagi mereka yang tertindas, yang miskin dan lemah, bahkan orang asing. Hal ini bisa dipahami, karena Alkitab berbicara tentang Allah yang universal, Allah yang Esa yang mengonrol sejarah umat manusia, sejarah bangsa-bangsa, bahkan menguasai dan memelihara alam semesta, termasuk makluk-makluk lain. Karena itu pada bagian ini saya ingin memberikan beberapa pemikiran dari sudut Perjanjian Lama. ${ }^{17}$

\section{Beberapa Pemikiran yang Berhubungan Dengan Cara Membaca dan Pokok-Pokok Penting yang Menunjang Kehidupan Bersama dalam Kemajemukan}

\subsection{Cara Membaca Alkitab}

Sebelum saya berbicara tentang cara membaca Alkitab, terlebih dahulu saya mau berbicara tentang doktrin gereja yang hanya terpaku pada formulasi-formulasi mati yang dirumuskan bapabapa gereja, tetapi tanpa memperhatikan apa yang ada di balik formulasi-formulasi itu. Padahal untuk mendapatkan pesan atau tujuan-tujuan formulasi itu hanya bisa ditemukan ketika gereja berani melakukan reinterpretasi terhadap pokok-pokok pengajaran iman kristen yang sudah membeku selama berabad-abad. Namun dalam menginterpretasikan pokok pengajaran iman kristen harus mulai dengan mempertanyakan hal-hal seperti, mengapa Bapa-bapa Gereja dulu merumuskan sebuah doktrin seperti yang mereka rumuskan dan yang sudah menjadi tradisi gereja selama berabad-abad. Sebab jika mereka berteologi pada zaman modern ini belum tentu rumusan atau teologi mereka seperti itu. Perlu dipertanyakan apa penyebab dan apa tujuan bapa-bapa gereja bersidang dan merumuskan pemikiran mereka? Perlu dipertanyakan masyarakat yang bagaimanakah yang mereka harapkan dari rumusan mereka pada masa itu? Pertanyaan-pertanyaan itu penting dijawab dengan melakukan penelitian terhadap latarbelakang masalah untuk menemukan tujuan dan dalam rangka menjawab persoalan apa masa itu. Juga untuk menemukan makna hakiki dari sebuah rumusan pengajaran masa itu. Yang pasti doktrin-doktrin atau rumusanrumusan masa itu bermaksud memberikan jalan keluar bagi perdebatan-perdebatan yang meresahkan umat atau masyarakat pada umumnya.

Hal berikut yang bisa dilakukan gereja adalah dengan cara membaca atau penafsirkan teks-teks Alkitab secara diakronis ataupun holistik. Penafsir perlu mempertanyakan, mengapa teks alkitab berkata seperti ini atau seperti itu? Apabila kita tidak melihat apa-apa yang ada di balik teks, maka teks alkitab tidak akan mengubah apa-apa. Cara menafsir diakronis memang bukan satu-satunya cara menafsir, namun cara ini merupakan salah satu cara menafsir yang dapat mengurangi berkembangnya faham-faham fundamentalisme yang cenderung kepada berkembangnya kehidupan keagamaan yang intoleran atau eksklusif. Keadaan seperti ini bisa terjadi pada pemeluk semua agama, bukan hanya agama tertentu.

\footnotetext{
${ }^{17}$ Selanjutnya disingkat PL.
} 
Menurut Sri Wismoady Wahono, penyebab frakmentasi dalam agama adalah akibat dari pemahaman yang sempit terhadap bagian-bagian Kitab Suci agama yang di anut. Ada orang yang membaca dan berusaha memahami bagian tertentu atau satu ayat tertentu oleh penganut agama, lalu apa yang dipahaminya yang sedikit atau ayat tertentu itu dianggap atau diyakini sudah mewakili pemberitaan seluruh Kitab suci agama yang dimaksud. Selanjutnya mereka akan memperdalam pemahaman mereka itu dan akhirnya mereka mengklaim apa yang mereka pahami sebagai kebenaran satu-satunya. Selanjutnya mereka akan menilai pandangan yang berbeda dengan pemahaman mereka adalah sesat. Dengan cara menilai seperti itu, maka semua yang berbeda dengan mereka dianggap salah. Akibatnya lahirlah fanatisme agama yang berlebihan. ${ }^{18}$ Menurut saya, Fundamentalisme juga menyumbangkan kehidupan yang intoleran. Biasanya kaum fundamentalisme sebelum membaca Kitab Suci agama, mereka sudah terlebih dahulu memiliki prasangka yang akan menggiring pemikiran mereka kepada doktrin yang sudah mereka anut yang diklaimnya sebagai satu-satunya kebenaran. Teks manapun yang mereka baca dari Kitab Suci, harus mendukung doktrin yang itu-itu juga.

Kadang-kadang ada orang yang membaca satu ayat Kitab Sucinya lepas dari konteks teks atau pun lepas dari konteks di balik teks. Kata-kata dalam satu ayat dianggap sebagai kebenaran absolut yang non-negotiable, Orang-orang yang membaca Kitab Suci seperti itu sangat mudah menyalahkan orang yang tidak sepaham dengannya. Orang seperti ini cenderung suka menghakimi mereka yang berbeda pemahaman dengannya. Orang-orang yang membaca Kitab Suci seperti itu lebih sibuk mempersiapkan diri untuk perang argumentasi, sibuk menyalahkan atau menghakimi, bahkan sibuk mendiskreditkan orang-orang yang tidak sepaham dengannya daripada memelihara relasi sosial yang baik dengan sesama manusia, siapapun dia.

Pembacaan Alkitab secara holistik juga penting. Orang harus membaca Alkitab secara keseluruhan. Ada juga teks Alkitab yang menyatakan bahwa Tuhan menjaga jarak dari manusia atau jauh dari manusia. Karena itu, Allah berbicara lewat mimpi atau melalui malaikat kepada manusia. Namun ada juga teks Alkitab yang menyatakan bahwa Allah dekat dengan manusia di mana Allah berbicara langsung dengan manusia. Jika orang hanya pernah membaca teks yang menyatakan bahwa Allah itu jauh dari manusia, maka ia akan mengatakan manusia hanya jauh dari Allah. Dia hanya berbicara tentang Allah yang transenden, dan ia tidak akan berbicara tentang Allah yang imanen. Menurut Paul Joyce, pembacaan Alkitab dengan cara di atas dilakukan oleh kaum fundamentalis. Namun Paul Joyce tidak bermaksud mengejek atau pun merendahkan kaum fundamentalis, ia hanya mau menjelaskan bahwa cara menafsir yang digunakan kaum fundamentalis merupakan salah satu usaha untuk menafsir PL yang penuh dengan inkonsistensi dalam teks-teks PL. ${ }^{19}$ Walaupun usaha itu juga tidak memuaskan, karena tidak memberikan jawaban terhadap kesulitan-kesulitan yang ditemukan teks-teks PL. Akan tetapi, perlu juga dikatakan bahwa tafsiran yang bersifat alegori, hurufiah atau pun partial memungkinkan lahirnya kaum fundamentalisme atau pun penganut agama yang intoleran. Hal ini bisa lahir dari agama manapun.

\subsection{Tema-tema Sentral Dalam Alkitab Adalah Kehidupan, Kasih, Kebenaran, Keadilan, Pembebasan, Penebusan, Pengampunan, Damai Sejahtera dan Lain-Lainnya}

\footnotetext{
${ }^{18}$ S. Wismoady Wahono, Pro Eksistensi, Kumpulan Tulisan untuk mengacu Kehidupan Bersama, Jakarta, BPK Gunung Mulia, 2001, hl.16-19.

${ }^{19}$ Paul Joyce dalam John Rogerson (Editor), Studi Perjanjian Lama bagi Pemula, Jakarta, PT. BPK Gunung Mulia, 1993, hl. 148-150.
} 
Pengampunan, pembebasan, Penebusan dan lain-lainnya yang bersifat universal. Tema-tema sentral Alkitab itu merupakan kebutuhan seluruh umat manusia tanpa dibatasi oleh tembok-tembok kesukuan, kebudayaan, ras dan keagamaan. Tema-tema sentral Alkitab merupakan kebutuhan manusia lintas suku, ras, bangsa, budaya dan agama.

Tema-tema sentral tersebut bukanlah hasil pemikiran belaka, tetapi merupakan karya Allah yang menyelamatkan, membebaskan, menebus, mengampuni, dan yang mengasihi umat dalam sejarah perjalanan umat.Tema-tema ini dijabarkan melalui berbagai kisah, peraturan, ketetapan, peringatan dan hukum-hukum legal. Semua terus dikembangkan sesuai konteks dan zaman. Walaupun misalnya berbagai peraturan, ketetapan, peringatan dan hukum semakin berkembang, makna tema-tema sentral itu, tetap harus menjadi dasar, sumber dan inspirasi, bagi lahirnya berbagai kisah, peraturan, ketetapan, peringatan dan hukum baru yang ada dalam Alkitab.

Namun Kisah-kisah, peraturan, ketetapan, peringatan, kata-kata hikmat dan hukum-hukum legal itu sebahagian besar diadopsi/ditransformasi dan atau inkulturasi dari kebudayaan-kebudayaan dari berbagai suku, ras dan agama yang ada disekitar umat Allah. Dengan demikian budaya-budaya dari berbagai suku bangsa itu, baik suku yang merupakan bagian dari umat Allah, mau pun yang bangsa tetangga merupakan ruang di mana umat Allah beraktualisasi dan berefleksi. Contoh, Hukuman cambuk (LAI:tongkat) dalam U1. 25:1-4. Hukuman cambuk ini berlaku umum di Timur Tengah Kuno. Ketika bangsa Israel berinteraksi dengan bangsa-bangsa tetangga, mereka mengadopsi kebiasaan ini untuk mewujudkan kebenaran, keadilan dan kasih di tengah-tengah umat. Berbedanya hukum cambuk antara bangasa-bangsa tetangga dan pada umat Allah adalah dalam hal jumlah cambukan. Menurut peraturan bangsa-bangsa tetangga, jumlah pukulan cambuk bagi mereka yang bersalah menurut pengadilan adalah berkisar antara 29 kali sampai 100 kali pukulan. Sedangkan yang berlaku dalam komunitas umat Allah, jumlah cambukan hanya berkisar antara 20 kali sampai 40 kali. Menurut Ul. 25;3, cambukan 40 kali itu sesuai dengan pertimbangan kasih dan keadilan Allah. Pertimbangan itu terbaca dalam kalimat ayat 3 yang berbunyi, "empat puluh kali harus orang itu dipukuli, jangan lebih; supaya jangan saudaramu menjadi rendah di matamu, apabila ia dipukul lebih banyak lagi." Ayat ini mau mengatakan bahwa hukum Tuhan sangat memperhatikan nilai-nilai penyelamatan, penebusan, kasih dan keadilan Allah. ${ }^{20}$ Contoh lain yang memperlihatkan bagaimana berbagai budaya menjadi ruang aktualisasi umat adalah Kej. 2:4b-25. Menurut penelitian Hodma Sitorus, Kej. 2 ditulis dan merefleksikan berbagai budaya suku bangsa yang kemudian mejadi komunitas umat Allah (bandingkan Pancasila). Tujuannya untuk mengukuhkan kerajaan Daud dan mempersatukan bangsa-bangsa yang menjadi bagian dari kerajaan Israel Raya. Penulis Kej, 2:4b-25 memulai sejarah Israel dengan merangkai sejarah permulaan Israel yang disesuaikan dengan tradisi literatur bangsa-bangsa tetangga, yaitu Mesopotamia. Literatur Mesopotamia yang sudah dikenal penulis Kej. 2:4b-25, salah satunya adalah kisah-kisah penciptaan yang dinilai tepat untuk meletakkan Israel dalam kerangka universal. ${ }^{21}$ Contoh lain adalah nasihat-nasihat bagi kaum muda yang terdapat dalam sebagian Kitab Amsal.

Ketika bangsa Israel berefleksi tentang makna kehidupan yang bersumber pada karya-karya Allah yang menyelamatkan, yang membebaskan, yang menebus dan yang memberi keadilan, maka para hamba Tuhan bisa menggunakan ucapan-ucapan hikmat yang ada pada bangsa-bangsa sekitar Israel. Karena itu

\footnotetext{
${ }^{20}$ Barbas Ludji, Tafsiran beberapa Teks Perjanjian Lama, Bandung, penerbit: Bina Media Informasi, 2009, hl.79-83.

${ }^{21}$ HodmaParulian Sitorus, Pengukuhan Identitas Kesatuan Bangsa Israel (Studi Sosio-Politik terhadap Kisah Penciptaan Sumber Y, Kejadian 2:4b-25), Tesis Magister Teologi, STT Cipanas, 2018, hl.101.
} 
jika teks-teks Amsal dibandingkan dengan teks-teks Amen-em-opet dari Mesir, sebagian teks Amsal memilki kesamaan dengan teks-teks Amen-em- opet dari Mesir yang sudah ada sejak abad ke-14 sM. Contoh, Amsal 22:24, "Jangan berteman dengan orang yang lekas gusar, jangan bergaul dengan seorang pemarah." Sejajar dengan Kitab Amen-em-opet 11:13,14, "Jangan berteman dengan orang bernafsu, jangan mendekati dia dan bercakap-cakap dengannya." Masih banyak lagi ayat yang bisa menjadi contoh. Karena Teks Amen-em-opet lebih tua usia penulisannya daripada Kitab Amsal, maka para orang bijak penulis Kitab Hikmat Amsallah yang mengambil alih dari teks-teks Amen-em-opet. ${ }^{22}$ Demikian juga Kitab Ayub yang berkaitan dengan tradisi Ayub di Babel. Ayat-ayat Kitab Ayub sebagian juga ada kesamaannya dengan ayat-ayat dalam tradisi Ayub di Babel. ${ }^{23}$ Walaupun demikian, antara bagian Alkitab yang mengadopsi budaya dari bangsa-bangsa dan agama lainnya dan budaya-budaya bangsa lain tetap memiliki perbedaan yang hakiki. Sebab Firman Tuhan yang terdapat dalam bagian kitab-kitab tadi dilandasi dan diinspirasi oleh karya penyelamatan Allah yang dirumuskan para hamba Allah dalam tematema sentral dalam Alkitab, khususnya PL. Masih banyak bagian Alkitab yang merupakan adopsi atau trasformasi dari berbagai budaya yang ada di sekitar umat Allah, tetapi semuanya mengandung tema-tema sentral dari karya penyelamatan, pembebasan, penebusan, kasih, kebenaran dan keadilan Allah.

Apa yang sudah kita bahas di bagian ini memperlihatkan kepada kita bagaimana pentingnya dunia sekitar kita berupa berbagai suku, ras, budaya dan orang beragama lain; mereka bukanlah musuh yang harus dijauhi, tetapi menjadi bagian dari kehidupan sebuah komunitas, manusia dengan segala sesuatu yang melekat pada dirinya, sekaligus juga konteks tempat umat kristen berinteraksi, berrefleksi dan beraktulisasi.

\subsection{Hasil Penelitian Dengan Metode Diakronis (Kritisime Historis)}

Hal berikut yang ingin saya kemukakan adalah Kej. 3 yang oleh orang kristen memahaminya tidak lebih daripada kisah kejatuhan manusia dalam dosa. Pada hal ada sudut pandang lain juga yang kita temukan pada kisah Kej.3. melalui penelitian diakronis, kita mendapatkan bahwa pada Kej. 3 ada pesan keadilan sosial dan menolak tindakan penindasan terhadap sesama manusia. ${ }^{24}$ Tema sentral, keadilan Allah dijabarkan melalu kisah Kej. 3 yang disampaikan kepada umat Allah pada zaman Kerajaan Daud. Kerajaan Israel Raya yang dipimpin Raja Daud selama empat puluh tahun. Israel Raya merupakan bangsa yang terdiri dari berbagai suku bangsa, budaya dan agama. Dalam masyarakat pun terjadi pembagian strata sosial. Ada kelas pekerja yang menyediakan kebutuhan kelas bengasawan. Kelas pekerja adalah suku-suku bangsa taklukan. Pembagian strata soial seperti itu merupakan gambaran tentang adanya sistim feudal yang mustinya tidak beleh ada pada umat Allah. Sebagian masyarakat harus mengeluarkan keringat untuk menyediakan kebutuhan para penguasa. Dalam stuasi seperti inilah Penulis J (Y) ${ }^{25}$ menyampaikan

\footnotetext{
${ }^{22}$ Weeler H. Robinson, Inspiration and Revelation in the Old Testament, Oxford, Clarendon, 1960, hl. 235,236 dan 495 (lihat Barnabas Ludji, Pemahaman Dasar Perjanjian Lama 2, Bandung, Penerbit: Bina Media Informasi, hl.188189).

${ }^{23}$ Ibid. Barnabas Ludji, hl. 189.

${ }^{24}$ Agustinus Setiawidi, Menafsirkan Kejadian 3:1-24 dalam konteks J:Kritisisme Historis dan Eksegese Teologis dalam Robert Borong dkk., (penyunting) Berakar di dalam Dia \& Dibangun atas Dia, Jakarta, BPK Gunung Mulia, 1998, hl. 27-40.

${ }^{25} \mathrm{~J}(\mathrm{Y})$ berasal teori sumber yang masih digunakan untuk studi Alkitab dengan metode diakronis atau kritisisme Historis. Sumber Y atau Yehwis ditulis pada zaman Daud dan Salomo. Sumber Y ditulis oleh Para Imam, (lihat Barnabas Ludji, Pemahaman Dasar Perjanjian Lama 1, Bandung, Bina Media Informasi, 2009, hl. 48,49.)
} 
kisah Kej. 3 dengan tujuan menghapus penindasan dan ketidakadilan yang terjadi dalam Kerajaan Daud. Untuk menguatkan fondasi Kerajaan Daud yang terpecah oleh perbedaan suku dan budaya serta perbedaan kelas masyarakat. Seluruh masyarakat harus hidup dalam kesetaraan. ${ }^{26}$ Tema sentral keadilan sosial dijabarkan dalam bentuk narasi Kej.3. Dari narasi ini, kita mendapatkan tema sentral dalam nilai keadilan sosial, di mana umat manusia hidup dalam kesetaraan. Kesetaraan merupakan nilai kemanusiaan yang universal. Jika umat beragama memiliki nilai ini, maka dia memiliki moral yang selalu menghargai keberadaan setiap manusia dengan segala sesuatu yang melekat pada dirinya, seperti budaya dan agamanya. Orang seperti itu mustinya tidak lagi bersikap dikotomi terhadap umat manusia. Ia juga tidak mungkin melakukan penghinaan yang merendahkan sesama hanya karena berbeda suku, budaya dan agama. Orang-orang yang menyadari kesetaraannya dengan sesamanya, berarti ia sudah memiliki sumber daya manusia yang unggul dalam hal spiritalitas.

Pokok berikutnya yang berhubungan dengan tema-tema sentral keadilan, kebenaran, kasih, pembebasan, dan penebusan adalah hukum-hukum dan peraturan yang berkaitan dengan orang miskin dan orang lemah yang sering menjadi korban penindasan para penguasa dan elit bangsa yang lain. Bukankah tema tentang orang miskin juga menjadi isu politik yang sentral secara nasional, khususnya pada menjelang pemilu dan pilkada? Kadang kadang yang dipersoalkan adalah hal kemiskinan, kadang-kadang tentang orang miskin. Ketika para politikus berbicara tentang kemiskinan ataupun orang miskin, persoalannya ialah apakah mereka berbicara tentang kepentingan orang miskin, atau kepentingan para politikus sendiri?

Alkitab banyak berbicara mengenai orang miskin, berkaitan dengan tema-tema sentral Alkitab yang sudah disebutkan. Kitab Taurat mengayomi orang miskin, lemah, janda, yatim dan orang asing (Kel. 22: 21,22,25; 23:6; Im. 25:35-38). Kaum marjinal mendapat perhatian khusus dari seluruh Kitab. Jika umat Allah berbicara tentang kebenaran, keadilan, penebusan, kasih dan lain-lainnya, maka kaum marginal selalu mendapat perhatian. Berbagai peraturan, ketetapan, dan hukum selalu mengakomodasi kepentingan orang miskin. Kebenaran dan keadilan memiliki makna bahwa Allah berpihak kepada mereka, karena mereka ditindas oleh mereka yang kuat, penguasa dan orang kaya. Para nabi sangat pengecam perbuatan para elit yang menindas dan yang mengeksploitasi orang miskin dan lemah. Salah satu contoh, Amos 2:6-8.

\subsubsection{Amos 2:6-8}

6."Karena tiga perbuatan jahat Israel, bahkan empat, Aku tidak akan menarik kembali keputusanKu:

Oleh karena mereka menjual orang benar karena uang dan orang miskin karena sepasang kasut;

7. mereka menginjak-injak kepala orang lemah ke dalam debu dan membelokkan jalan orang sengsara;

anak dan ayah pergi menjamah seorang perempuan muda sehingga melanggar kekudusan namaKu;

8. mereka merebahkan diri di samping setiap mezbah di atas pakaian gadaian orang, dan minum anggur orang-orang yang kena denda dirumah Allah mereka."

\footnotetext{
${ }^{26}$ Agustinus Setiawidi, hl. 39-40.
} 
Penggunaan kata fesha (perbuatan jahat) mau menegaskan bahwa kejahatan umat Israel di bidang kehidupan sosial-ekonomi bukan sekedar pelanggaran hukum dan peraturan agama, ataupun hukum moral, melainkan merupakan pemberontakan melawan Allah (lihat Snaith 1962: hlm. 60). ${ }^{27}$ Karena itu, anak kalimat 'Beginilah firman Tuhan:' menegaskan bahwa bangsa Israel tidak berhadapan dengan pejabatpejabat agama seperti nabi atau imam, melainkan berhadapan langsung dengan Allah mereka. Kejahatan Israel di bidang sosial-ekonomi dirinci oleh Amos pada ayat-ayat selanjutnya (2: 6c-8). Saya akan mulai dengan menyoroti kata 'orang benar, tsadiq (oran benar). Achard (1984: hlm. 21) menerjemahkan kata ini dengan kata innocent ('tidak bersalah') sebagai lawan kata guilty ('bersalah'). Archard juga melihat hubungan yang erat antara kata tsadiq dengan kata 'eviyon (miskin). Kedua kata tersebut jelas tidak sinonim, tetapi menunjuk pada dua kelompok orang yang menjadi korban ketidakadilan. Amos 2: 6-8 merupakan klimaks nubuat Amos, yang berbicara tentang masalah sosial-ekonomi. Pemberitaaan Amos ini mempunyai kesamaaanya dengan nubuat para nabi yang sezaman dengannya, misalnya, Yesaya dan Mikha.

Bentuk-bentuk penindasan yang dilakukan para pejabat dan orang-orang kaya adalah sebagai berikut. Pertama, para pejabat melakukan pengadilan yang curang, karena mereka menerima suap. Kedua, menjual orang benar, karena hutang yang sangat kecil. Dalam praktik seperti ini tampak martabat seseorang diinjak-injak. Ketiga, kaum wanita dipaksa melakukan hubungan suami istri, karena kedudukan mereka yang lemah baik secara ekonomi maupun secara sosial. Sikap para pejabat dan orang-orang kaya pada waktu itu dinilai oleh Nabi Amos sebagai pemberontakan kepada Allah. Dengan demikian pelanggaran hukum dan penindasan-penindasan yang dilakukan sekelompok kaum elite tidak hanya merupakan kejahatan yang bersifat sosiologis-ekonomis, tetapi bersifat teologis. Karena itu, Amos bukan seorang sosiolog tetapi seorang reformator teologi. Dalam hal ini Amos terpanggil untuk menegakkan perjanjian Tuhan dengan umat-Nya, karena perjanjian itu telah dilanggar oleh umat, melalui praktik-praktik ketidakadilan. Itulah sebabnya Amos dan Yesaya sangat menekankan keadilan dan kebenaran dalam pemberitaan mereka. Nabi Amos adalah nabi Tuhan yang mencintai keadilan dan kebenaran (Amos 5:24). Orang yang mencintai keadilan dan kebenaran adalah orang yang tidak suka pada penindasan, perampasan dan kekerasan lain terhadap sesamanya tanpa memandang bulu. Sebab membedakan-bedakan manusia atau mendikotomikan manusia termasuk dalam perbuatan ketidakadilan. Orang yang mencintai keadilan dan kebenaran tidak mungkin membeda-bedakan manusia. Ia akan menghargai, menghormati sesamanya sebagai saudaranya. Ia akan membela sesamanya yang miskin, yang lemah yang tertindas, yang terpinggir tanpa melihat asal-usul ataupun latar belakang suku, budaya dan agama sekalipun. Saya teringat dan menghargai para pejuang-pejuang keadilan dan kebenaran yang dengan rela berkorban melakukan kegiatan mereka pada zaman Orde Baru. Mereka merelakan nyawanya dan beberapa di antara mereka dinyatakan sebagai orang yang hilang setelah mereka diculik pada tahun 1998. Sampai sekarang belum ditemukan jejaknya. Di antara mereka ada yang beragama Kristen Katolik (sebagai orang yang sangat dicari keamanan pada masa itu), ada yang beragama Islam ada orang Kristen Protestan dan ada pula yang beragama Hindu Budha. ${ }^{28}$ Mereka yang terlibat dalam perjuangan ini bersatu padu tanpa batas-batas agama atau pun suku. Kalau orang yang menyebut dirinya sebagai pecinta keadilan dan kebenaran lalu berkata sesama saya hanya yang seagama, atau sesuku, yang lain tidak, maka pada dirinya tidak ada

\footnotetext{
${ }^{27}$ Davies, Ery W., Prophecy and Ethics, Sheffield. (JOST), 1981: 25: mengatakan bahwa para nabi jarang berbicara tentang pelanggaran hukum tertentu. Mereka menaruh perhatian pada kegagalan bangsa Israel dalam memelihara hubungan dengan Tuhannya secara keseluruhan. Dengan kata lain, umat gagal memberikan respon terhadap penyelamatan Tuhan dalam sejarah. Kegagalan Israel melaksanakan kehendak Allah merupakan manifestasi kegagalan memberikan respon terhadap kemurahan Tuhan. (Lihat Norman H. Sanaith, The Distinctive Ideas of the Old Testament, London, Epwrth, 1962).
}

\footnotetext{
${ }^{28}$ Arif Zukilfli cs. (Penyunting) Wiji Thukul. Teka Teki Orang Hilang, Jakarta, KPG (Kepustakaan Populer
} Gramedia), hl. 74-75, 146-151. 
keadilan, tidak ada kebenaran. Sebab keadilan dan kebenaran adalah salah satu tema sentral dalam Alkitab dan pasti bersifat universal. Semua manusia bahkan semua makluk senantiasa mendambakan keadilan dan kebenaran dalam kehidupannya. Demikianpun ketika orang memiliki kasih dan tema sentral Alkitab yang lainnya, pasti dia bermoral mengasihi, menebus, membebas dan mengampuni yang lintas suku, bangsa, ras dan agama.

Yes. 5:16: "Tetapi TUHAN semesta alam akan ternyata maha tinggi dalam keadilan-Nya, dan Allah yang maha kudus akan menyatakan kekudusan-Nya dalam kebenaran-Nya.”

Spiritual umat Allah yang diharapkan dan yang tertinggi terwujud seperti yang terdapat dalam teks-teks Kerajaan Mesias.

\subsubsection{Melalui Tulisan ini Saya Memberikan Contoh dari Yesaya 11:1-9}

1 Suatu tunas akan keluar dari tunggul Isai, dan taruk yang akan tumbuh dari pangkalnya akan berbuah.

2 Roh Tuhan akan ada padanya, roh hikmat dan pengertian,

roh nasihat dan keperkasaan, roh pengenalan dan takut akan TUHAN;

3 ya, kesenangannya ialah takut akan TUHAN.

Ia tidak akan menghakimi dengan sekilas pandang saja atau menjatuhkan keputusan menurut kata orang.

4 Tetapi ia akan menghakimi orang-orang lemah dengan keadilan, dan akan menjatuhkan keputusan terhadap orang-orang yang tertindas di negeri dengan kejujuran;

ia akan menghajar bumi dengan perkataannya seperti dengan tongkat, dan dengan nafas mulutnya ia akan membunuh orang fasik.

$5 \quad$ Ia tidak akan menyimpang dari kebenaran dan kesetiaan, seperti ikat pinggang tetap terikat pada pinggang.

6 Serigala akan tinggal bersama domba dan macan tutul akan berbaring di samping kambing.

Anak lembu dan anak singa akan makan rumput bersama-sama, dan seorang anak kecil akan menggiringnya.

$7 \quad$ Lembu dan beruang akan sama-sama makan rumput dan anaknya akan sama-sama berbaring, sedang singa akan makan jerami seperti lembu.

$8 \quad$ Anak yang menyusu akan bermain-main dekat liang ular tedung dan anak yang cerai susu akan mengulurkan tangannya ke sarang ular beludak

9.Tidak ada yang akan berbuat jahat atau yang berlaku busuk di seluruh gunung-Ku yang kudus, sebab seluruh bumi penuh dengan pengenalan akan TUHAN, seperti air laut yang menutupi dasarnya.

Nubuat Yesaya pada pasal ini mau menggambarkan bahwa raja yang dimaksud adalah Daud kedua yang berasal dari keluarga sederhana dari kota kecil Betlehem, dan bukan dari Yerusalem. Tunggul Isai itu memiliki kewibawaan yang menyamai Daud. Kesamaan keduanya tampak ketika keduanya sama-sama menerima Roh Allah (Yes. 11:2, band. 1 Sam. 16:13; 2Sam, 23:2 dst.). Roh Tuhan merupakan karunia pertama yang diterima Tunggul Isai (Daud kedua). Pemberian Roh ini menyejajarkan Daud kedua dengan pemimpin kharismatis, Daud. Pemberian Roh ini mau menggambarkan bahwa sang raja baru memiliki kesempurnaan pemerintahan Allah dan merupakan kritik dan kecaman terhadap raja yang sedang 
memerintah ${ }^{29}$ yang diwarnai oleh tindakan-tindakan kelaliman, ketidakadilan, penindasan dan perampasan terhadap yang miskin dan lemah. Kesempurnaan pemerintahan raja baru ini bukan saja baru ada pada masa yang akan datang, tetapi keadaan yang sudah pernah terjadi pada zaman pemerintahan Daud; suatu keadaan yang sudah pernah dialami oleh bangsa Israel. Karena itu pemberitaan Yesaya ini juga mendorong agar raja baru yang melaksanakan pemerintahannya seperti yang pernah dilakukan Raja Daud. Karajan Daud menjadi prototipe bagi kerajaan Israel selanjutnya, karena keadaan itu pernah terjadi. Sangat wajar jika kerajaan Daud yang berlangsung selama 40 tahun itu menjadi Prototipe, sebab lamanya pemerintahan Daud itu sudah cukup memberikan alasan bahwa pemerintahan Daud itu adalah pemerintahan yang berkeadilan dan mengacu kepada kebenaran. Semua sama-sama menikmati keadilan sosial berupa kemakmuran bersama, kedamaian bersama, ketenteraman bersama, seperti yang digambarkan Yesaya pada ayat-ayat di atas. Walau masyarakatnya merupakan masyarakat yang pluralis suku, ras bangsa dan agama. Pada masa Salomo keadaannya masih bertahan. Memang para nabi atau para imam melalui tulisan Kitab Raja-raja mangritik pemerintahan Salomo yang sangat toleran dengan istriistrinya dan tentu saja juga suku-suku istrinya yang di bawah pemerintahan Salomo. Sikap toleran Salomo itu diperlihatkan, ketika ia mendirikan kuil-kuil sebagai tempat sitri-istrinya beribadah kepada dewa-dewa yang mereka sembah. Akan tetapi di lain pihak, para imam pada zaman sesudah pembuangan para imam justru menilai Salomo sebagai yang lebih besar daripada raja-raja sebelumnya dan raja-raja sesudahnya. Bahkan dalam 2 Tawarikh, Salomo dinilai sebagai mesias anak Daud yang dinantikan.Teks-teks Alkitab yang memperlihatkan sikap toleran dan universal dalam Kitab Kejadian dan kitab-kitab lainnya dalam Kitab Taurat berasal dari Zaman Daud dan Salomo.

Karunia-karunia Roh yang diberikan Raja baru itu meliputi seluruh dimensi kehidupan manusia yang akan mendatangkan syalom (damai sejahtera) bagi seluruh umat manusia dan bahkan seluruh makluk. Karunia hikmat dan pengertian menegaskan bahwa raja baru itu menerima kemampuan melakukan pengadilan dengan baik dan seadil-adilnya. Raja memiliki kemampuan untuk melindungi orang miskin dan lemah dari penindasan dan kejahatan (ayat 4,5). Sedangkan karunia pengertian raja menerima kemampuan dari Tuhan untuk menentukan kebijakan bagi kegiatan politik, baik dalam negeri mau pun luar negeri.

Pasangan karunia Roh berikutnya ialah Roh Nasihat dan Keperkasaan. Kedua pasangan karunia Roh ini merupakan pemberian Allah yang membuat sang raja mampu mengatur strategi militer dan politik. Dalam melaksanakan tugasnya ia tidak lagi memerlukan nasihat-nasihat, karena kemampuannya untuk itu sudah lengkap. ${ }^{30}$ Dengan demikian di bidang pertahanan sang raja mampu menentukan siapa orang yang paling pas menduduki semacam menteri pertahanannya, sehingga kerajaan mampu mengatasi seranganserangan militer bangsa lain atau pun ancaman pemberontak dari dalam. Keamanan terjamin, rakyak makmur, damai sejahtera terasa sekali dalam kehidupan umat.

Karunia Roh berikutnya adalah roh pengenalan dan roh takut akan Tuhan. Pasangan karunia Roh ini memberikan kemampuan kepada raja yang baru itu untuk mengatur kehidupan keagamaan, sehingga umat memiliki sikap ibadah yang benar kepada Allah. Pasangan karunia Roh ini sangat akrab dan berfungsi sebagai sumber hikmat (Jensen, 1984: hl.132). Pengenalan dan takut akan Tuhan juga kebenaran melalui kebijakan-kebijakan dan tindakan-tindakan konkrit dalam mengatur, melindungi dan memberi damai sejahtera bagi seluruh umat yang pluralis ${ }^{31}$ dan bahkan damai sejahtera meliputi sesama

\footnotetext{
${ }^{29}$ Barnabas Ludji, Kerajaan Mesias, (telaah Kritis Kitab Amos, Yesaya dan Mikha) Jakarta, Penerbit: Sekolah Tinggi Teologi Jakarta, 1999:12.

${ }^{30}$ Ibid. hl. 14.

${ }^{31}$ Kerajaan Daud adalah kerajaan yang pluralis dan universal. Hal ini tergambar juga dalam pemberitaan Amos tentang kerajaan mesianis (9:11-15). Pada pasal ini, Amos juga mengacu kepada karajaan Daud yang pernah ada dua abad sebelum nubuat pada pasal ini. Pada waktu itu, kerajaan Daud itu meliputi multi suku dan bangsa, seperti bangsa Edom, orang Filistin, orang, orang Arama (Syria), orang Moab, Amon,(lihat Barnabas, Kerajaan Mesias, hl. 6), Arab, Filistin dan suku-suku Israel sendiri.Para Imam atau pun para nabi pasa itu menuliskan firman Tuhan untuk menegur umat Allah yang berlaku tidak adil terhadap bangsa-bangsa atau pun suku bangsa lainnya. Misalnya
} 
makluk-makluk lain (ayat 6-9). Manusia dan sesama makluk hidup berdampingan dalam kedamaian. Teleransi dan saling menghormati dan menghargai serta saling mengasihi di antara sesama manusia dan sesama makluk akan terjadi. Perang akan berakhir. Hal ini memperoleh penegasan dari penulis Kitab Mikha (4:3). ${ }^{32}$ Ayat ini sebenarnya sedang membayangkan situasi ketika Daud dan Salomo memerintah di Israel, sekaligus menjadi harapan pada masa pemerintahan saat itu dan yang akan datang. Hujan melimpah akan membasahi padang rumput dan tanah akan memberikan hasil yang melimpah. Hal ini ditegaskan oleh nubuat Amos pada pasal 9. ${ }^{33}$

\section{Penutup}

a. Roh Globalisasi memang telah melanda dunia, sehingga dunia yang satu dan dunia yang lain semakin terhubung dan terasa dunia sudah menyatu. Akan tetapi di pihak lain, ada perkembangan yang juga harus diwaspadai, bahwa manusia semakin primordial yang bersifat suku atau pun agama. Kelompok-kelompok masyarakat semakin eksklusif. Dalam perkembangan muncullah pengelompokan in Group dan Out Group.

b. Perkembangan lain ialah adanya geopolitik yang menggabungkan kelompok agama yang eksklusif dan kepentingan kelompok politik tertentu. Kedua kelompok bergabung dengan kepentingan yang berbeda satu sama lainnya. kelompok yang satu punya agenda a dan yang lainnya agenda $b$, keduanya saling memanfaatkan kekuatan.

c. Munculnya kelompok agama yang eksklusif/fundamentalis yang diakibatkan oleh cara membaca Kitab suci agama secara hurufiah dan partial. Orang membaca sepotong ayat lalu menganggapnya sebagai kebenaran satu-satunya atau seolah-oleh sudah mewakili kesaksian seluruh Alkitab.

d. Makna penebusan Allah meliputi seluruh dimensi kehidupan manusia. Allah menebus manusia dari dosa dan maut, tetapi juga menebus manusia dari situasi yang menindas. Ingat peristiwa keluaran dari Mesir. Termasuk menebus tanah milik yang dirampas orang. Menebus sesama dari kemiskinan. Semuanya itu diperhitungkan sebagai kebenaran dan keadilan Allah. Hanya orag yang memiliki kasih Allah yang mampu melakukan hal-hal di atas dengan mengabaikan batas-batas suku, ras, bangsa, budaya dan agama.

e. Sesama manusia dengan segala yang melekat pada dirinya, seperti budaya, agama, kehidupan sosial, politik dan sosial ekonominya, mereka adalah bahagian dari kehidupan orang kristen, di mana setiap orang percaya dapat berinteraksi dengan damai, dapat beraktualisasi dan berefleksi. Pada setiap agama pasti ada hal-hal yang baik yang bisa ditiru atau diambil menjadi milik gereja. Misalnya, hewan kurban yang disembelih untuk dibagi-bagikan kepada yang miskin dan berkekurangan. Tentu saja hal ini merupakan khabar sukacita konkrit bagi yang miskin. Dalam Alkitab orang

\footnotetext{
Kej. 12 di mana Abraham akan menjadi berkat bagi bangsa-bangsa. Kebenaran, keadilan, berkat tidak hanya untuk diri sendiri, tetapi juga bangsa lain.

${ }^{32}$ Mikha 4:3 merupan bagian dari teks kerajaan mesias, "Dia akan menjadi hakim antara banyak bangsa, dan akan menjadi wasit bagi suku-suku bangsa yang besar, sampai ke tempat yang jaug, mereka akan menempa pedangpedangnya menjadi mata bajak, dan tombak-tombaknya menjadi pisau pemangkas, bangsa tidak akan lagi mengangkat pedang terhadap bangsa, dan mereka tidak akan lagi belajar perang.

33 Amos 9:13-15 menggambarkan adanya siklus pertanian yang abnormal atau yang tidak biasa. Jarak waktu antara masa membajak dan masa menuai akan susul menyusul tanpa masa interval (ay. 13).
} 
kristen, hewan kurban juga banyak dibicarakan. Lalu apa salahnya kalau orang kristen pun memberikan hewan kurban kepada saudara-saudara muslim untuk disembelih bagi mereka yang membutuhkan. Selama ini hal-hal seperti itu tidak ada masalah. Saya pun selalu mendapat pembagian daging kurban pada waktu hari raya Idul Adha dan saya pun menerimanya. Masa kita hanya menerima, memberi juga bolehlah. Hal ini sudah benyak dilakukan oleh orang-orang yang mampu dan tidak dibatasi oleh batas-batas agama, suku dan budaya.

f. Orang-orang yang merasa memiliki kasih, karena penebusan Allah dalam Yesus Kristus, seharusnya bisa mengasihi semua orang, karena kasih Allah, kasih Kristus juga bersifat universal.

g. Jangan mengatakan bahwa dia orang yang memiliki kehidupan, kasih, keadilan, dan kebenaran, karena Allah, karena Kristus, jika dia masih eksklusif, masih membedabedakan manusia menurut agama, suku dan budaya dalam mengasihi, dalam mengadili ataupun dalam hal menolong yang lemah dan miskin. Kalau ada orang yang mau menolong orang dengan tujuan-tujuan tertentu, maka orang itu tidak memiliki kebaikan Allah.

h. Ketika kita berbicara tentang sumber daya manusia, jangan hanya berbicara tentang ekonomi, sosial, politik atau teknologi saja. Jika kita hanya unggul pada hal-hal yang disebutkan itu, maka keunggulan sumber daya manusia yang kita memiliki belumlah lengkap, jika kita belum memiliki spiritualitas tertinggi. Apa itu spiritulitas tertinggi itu? Menurut saya, spiritualitas tertinggi adalah jika seseorang melakukan kebaikan bagi orang lain tanpa embel-embelnya. Sebab itulah yang dimaksudkan dengan mengasihi Allah.

i. Jika sebuah komunitas menempatkan tema-tema sentral Alkitab sebagai acuan dalam kehidupannya, maka manusia tidak hanya hidup damai dengan sesama, tetapi juga berdamai dengan semua makluk. Yesaya 11 berbicara tentang itu, hal itu bukanlah hanya cita-cita, sebab ada ahli yang mengatakan bahwa keadaan seperti itu sudah pernah terjadi pada zaman dahulu kala. Di dunia Barat hal ini sudah sangat terasa. Burung-burung suka hinggap dijendala rumah untuk memperoleh makanan dari manusia. Burung-burung bersarang di pinggir jalan dan tidak ada orang mengganggu mereka. 


\section{DAFTAR PUSTAKA}

Achard, Robert Martin and Re'emi S. Paul, God's Peolple in Crisis: A Commentary on the Book of Amos and Lamentations, Edinburgh, The Handsel Press.

Agustinus Setiawidi,Dalam Robert Borong dkk. (penyunting), Berakar di dalam Dia \& dan dibangun di atas Dia, Menafsirkan Kejadian 3:1-24 dalam konteks J:Kritisisme Historis dan Eksegese Teologis, Jakarta, BPK Gunung Mulia, 1998.

Davies, Eryl W., Prophecy and Ethics, Sheffield, (JSOT), 1981.

Jensen, Joseph,Isaiah, 1-39, Old Testament Message 8, Wilmington, Michael Glazier, 1984.

Joyce, Paul, dalam John Rogerson (Editor), Studi Perjanjian Lama bagi Pemula, Jakarta, PT. BPK Gunung Mulia, 1993.

Kristiyanto, Eddy A., dan William Chang (editor), Multi Kulturalisme, Mozaik yang "harus" Serasi: Konflik Agama, Jakarta, Obor, 2014

Ludji Barnabas, Pemahaman Dasar Perjanjian Lama 1, Bandung, Bina Media Informasi.

---------------, Pemahaman Dasar Perjanjian Lama 2, Bandung, Bina Media Informasi.

-----------------, Kerajaan Mesias, Jakarta, Sekolah Tinggi Teologi Jakarta, 1999.

Samosir, Leonardus, dalam Eddy Kristiyanto. Willian Chang (editor), Multi Kulturalisme, Mozaik yang "harus" Serasi: Konflik Agama,Jakarta, Penerbit Obor.

Sitorus, Hodma, Pengukuhan Identitas Kesatuan Israel-Bangsa Israel (Studi Sosio-Politik terhadap Kisah Penciptaan Sumber Y, Kejadian 2:4b-25), Tesis Magister Teologi, STT Cipanas, 2018.

Sularso Sopater cs, (penyunting), Keadilan dalam Kemajemukan, Jakarta, Pustaka Sinar Harapan, hl. 106107.

Wahono, Wismoady S., Pro Eksistensi, Kumpulan Tulisan untuk mengacu Kehidupan Bersama, Jakarta, BPK Gunung Mulia, 2001.

Weeler H. Robinson, Inspiration and Revelation in the Old Testament, Oxford, Clarendon, 1960

Zukifli, Arif cs. (penyunting), Wiji Thukul. Teka Teki Orang Hilang, Jakarta, KPG (Kepustakaan Populer Gramedia).

Kompas, Sabtu, 12 Oktober, 2019 